\title{
Physicochemistry or physiology: cadmium uptake and effects of salinity and osmolality in three crabs of different ecologies
}

\author{
P. S. Rainbow ${ }^{1,2, *}$, W. H. Black ${ }^{2}$ \\ ${ }^{1}$ Department of Zoology, The Natural History Museum, Cromwell Road, London SW7 5BD, UK \\ ${ }^{2}$ Previously: School of Biological Sciences, Queen Mary, University of London, London E1 4NS, UK
}

\begin{abstract}
The effects of salinity and osmolality differences on the uptake rates of dissolved cadmium were investigated in 3 crabs of different ecologies - the euryhaline common shore crab Carcinus maenas, the extremely euryhaline Chinese mitten crab Eriocheir sinensis, and a more stenohaline crab, the velvet swimming crab Necora puber. This study tests predictions derived from the interpretations of the authors from a study of $\mathrm{Zn}$ uptake by the same crabs, in terms of the balance between physicochemical and counteractive physiological effects controlling trace metal uptake rates from solution. As predicted, reduced salinities caused increases in the cadmium uptake rate of E. sinensis as expected from the free metal ion model, with increased free cadmium ion availabilities in conditions of reduced chloride complexation. In the cases of C. maenas and N. puber, however, decreased salinity was associated with reduced cadmium uptake, a result interpreted in terms of a physiological response by these crabs to low salinity offsetting the physicochemical effect of increased free cadmium ion availability. This physiological response may include reductions in apparent water permeability with reduced salinities. Osmolality experiments showed that the physiological responses made by the crabs to decreases in salinity could not be explained simply by responses to changes in osmotic pressure of the medium. The interaction of physiology and physicochemistry controls rates of trace metal uptake from solution by these ecophysiologically distinct crab species.
\end{abstract}

KEY WORDS: Cadmium uptake $\cdot$ Salinity $\cdot$ Osmolality $\cdot$ Crabs $\cdot$ Carcinus maenas $\cdot$ Eriocheir sinensis Necora puber

\section{INTRODUCTION}

Aquatic invertebrates take up trace metals from solution across the cell membrane of permeable surfaces in contact with the medium. Possible transport routes include: (1) carrier-mediated transport whereby the metal is bound to a membrane carrier protein, (2) a selective membrane channel consisting of a protein with a hydrophilic core, (3) passive diffusion of lipidsoluble non-polar forms, and (4) endocytosis (Simkiss \& Taylor 1989, 1995, Tessier et al. 1994, Rainbow 1997, Rainbow \& Black 2002).
The free metal ion is a model for the form of metal that is available for transport across the cell membrane via a carrier protein or through a membrane channel, and hence for the most bioavailable form of many dissolved trace metals (Tessier et al. 1994, Campbell 1995). Correspondingly physicochemical factors that affect the availability of the free metal ion in solution have been shown to affect trace metal uptake rates by aquatic invertebrates (Rainbow 1997, Rainbow \& Black 2002). Such physicochemical factors include the presence of chelating agents that reduce the availability of free metal ions (Nugegoda \& Rainbow 1988, O'Brien et 
al. 1990, Rainbow et al. 1993), or changes in salinity that alter concentrations of inorganic anions such as chloride that complex particular metal ions (Nugegoda \& Rainbow 1989a,b, Rainbow et al. 1993, Rainbow \& Black 2002). For example, dissolved cadmium in seawater exists mostly as chloro-complexes (e.g. $\mathrm{CdCl}^{+}$, $\mathrm{CdCl}_{2}{ }^{0}, \mathrm{CdCl}_{3}{ }^{-}$) with only a small percentage (ca $2.5 \%$ ) as the free $\mathrm{Cd}^{++}$ion (Zirino \& Yamamoto 1972, Mantoura et al. 1978, Bruland 1983, Rainbow et al. 1993). Reductions in salinity reduce the amount of chloride present and increase the percentage of dissolved cadmium present as the free metal ion (Rainbow et al. 1993). Such physicochemical effects on the rates of uptake of trace metals by invertebrates are independent of the invertebrates themselves (Rainbow 1997, Rainbow \& Black 2002).

On the other hand, some aquatic invertebrates can affect the rate of trace metal uptake from solution by making a physiological response to changes in the medium, for example to salinity reduction (Rainbow et al. 1993, Rainbow \& Kwan 1995, Rainbow \& Black 2002). Such physiological intercession that affects trace metal uptake rates is by no means a universal feature of aquatic invertebrates, and seems to be a characteristic of particular euryhaline estuarine invertebrates (Rainbow 1997, Rainbow \& Black 2002). For example, one possible physiological response to low salinity by such invertebrates is a reduction in apparent water permeability (AWP) (Rainbow \& Kwan 1995, Rainbow \& Black 2001), a side effect of which appears to be reduction in the rates of trace metal uptake from solution (Rainbow \& Black 2002). Furthermore, free cadmium ions are also of approximately the same ionic radius (0.92 $\AA$ ) as calcium ions (0.94 A) (Williams \& Frausto da Silva 1996), and it is inevitable that some Cd ions will cross cell membranes in calcium pumps (Simkiss \& Taylor 1995, Rainbow 1997), with the importance of this route of entry varying with organism and its physiological state (Wright 1977, 1980, Rainbow 1997).

Rainbow \& Black (2002) used an ecological series of 3 crabs to investigate the interaction of physiological and physicochemical factors affecting the uptake of dissolved zinc, choosing crabs with different potential to make physiological responses to changes in salinity: (1) Carcinus maenas, the common shore crab, a euryhaline species able to live on shores, in estuaries and sublittorally in fully marine conditions. This crab is known to make physiological responses to salinity variation including changes in apparent water permeability (Rainbow \& Black 2001). (2) Eriocheir sinensis, the Chinese mitten crab, which spends its adult life in rivers, migrating to estuaries to breed. This crab is extremely euryhaline, being able to occupy the full salinity gradient from freshwater to marine. (3) Necora puber, the velvet swimming crab, occurring from the lower shore down to sublittoral marine habitats. This crab was originally chosen as an example of a stenohaline marine species. It can, however, make some physiological response to salinity change (Rainbow \& Black 2001) but still serves as an example to the more stenohaline end of the gradient of euryhalinity represented here (Rainbow \& Black 2002).

A reduction in salinity is correlated with a decrease in chloride complexation of zinc, increasing the availability of the free zinc ion, leading to an expectation of an increase in zinc uptake rate (Rainbow et al. 1993, Rainbow 1997). A decrease in AWP with the same reduction in salinity would on the other hand reduce the uptake of zinc from solution (Rainbow \& Black 2001, 2002). Thus, the net effect of a reduction in salinity on dissolved Zn uptake by a crab would be the result of the balance between the physicochemical enhancement of $\mathrm{Zn}$ uptake rate via increased availability of the free $\mathrm{Zn}$ ion, and the physiological reduction of Zn uptake by a decrease in apparent water permeability (Rainbow \& Black 2002). Differences between crab species will depend on the relative strengths of these 2 counteracting effects, the strength of any physiological response probably being related to euryhaline ability.

As predicted, the study on the uptake of dissolved zinc by the crabs showed clear differences between the 3 species (Rainbow \& Black 2002). The rate of uptake of Zn by Carcinus maenas and (initially unexpectedly) Necora puber decreased with reduction in salinity; this was interpreted as the result of the physiological response of these crabs to salinity reduction offsetting the physicochemical effect of increased free Zn ion availability (Rainbow \& Black 2002). (The physiological response is partly explained by changes in AWP, although experiments manipulating solution osmotic pressures independent of salinity and chloride concentrations indicated that other physiological responses may also have been coming into effect.) On the other hand, reduced salinities caused increases in the Zn uptake rate of Eriocheir sinensis, as expected from the free metal ion model (Rainbow \& Black 2002). E. sinensis has a low AWP compared to the other 2 crabs, but does not make any further change to AWP in response to salinity reduction in contrast to the other 2 species (Rainbow \& Black 2001), leaving physicochemical changes to control changes in Zn uptake rate (Rainbow \& Black 2002).

The interpretations made by Rainbow \& Black (2002) lead to predictions that can be tested by investigation of the effects of salinity and osmolality changes on cadmium uptake. Like $\mathrm{Zn}, \mathrm{Cd}$ in seawater is complexed by inorganic anions with even greater dependence on chloride than is the case for $\mathrm{Zn}$ (Rainbow et al. 1993). Thus, reductions in salinity cause even 
greater increases in the availability of the free metal ion than in the case of $\mathrm{Zn}$, particularly at the bottom end of the salinity range (Rainbow et al. 1993). The interpretations of Rainbow \& Black (2002) on the interaction of physicochemistry and physiology on the uptake of $\mathrm{Zn}$ lead to the following predictions for the uptake of Cd by Carcinus maenas, Eriocheir sinensis and Necora puber. (1) Reduced salinity will decrease the rate of uptake of $\mathrm{Cd}$ by C. maenas and N. puber; (2) reduced salinity will increase Cd uptake by E. sinensis, with particularly strong increases at the lower end of the salinity gradient.

Experiments to measure $\mathrm{Cd}$ uptake were therefore carried out under identical physicochemical conditions to those used for Zn uptake (Rainbow \& Black 2002) to test the above predictions.

\section{MATERIALS AND METHODS}

Adult male Carcinus maenas (wet weight 60 to $80 \mathrm{~g}$ ) and Necora depurator (wet weight 20 to $45 \mathrm{~g}$ ) were obtained from the University Marine Biological Station, Millport, Isle of Cumbrae, Scotland, after collection locally. Adult male and female Eriocheir sinensis (wet weight 70 to $110 \mathrm{~g}$ ) were collected from the filter screens of Lots Road power station, Chelsea, on the estuary of the River Thames in west London. Although the moult stage was not determined specifically for each crab, any crab showing any apparent sign of not being in intermoult was discarded. All crabs were therefore assumed to be in intermoult. C. maenas and $N$. puber were transferred on collection to aquaria and maintained in natural seawater at a salinity of 33 , whilst $E$. sinensis were maintained in artificial seawater (Tropic Marin Neu [TMN], Tropicarium Buchslag) at a salinity of 15 . All crabs were kept at $10^{\circ} \mathrm{C}$ under a $12 \mathrm{~h}$ light:12 $\mathrm{h}$ dark cycle and fed with lambs' heart 3 times a week.

For acclimation and for all experiments, crabs were maintained in artificial seawater (TMN). The choice of a reproducible medium was crucial to these experiments, because the physicochemistry of the seawater medium has a very significant effect on the uptake of trace metals such as cadmium by crustaceans (Rainbow 1997, Rainbow \& Black 2002). Crabs were acclimated in TMN of a chosen salinity and osmolality for 7 d (see Henry \& Cameron 1982, Mantel \& Farmer 1983) before experimental exposure to cadmium. The sodium concentration of the blood of each crab was measured daily to confirm the process of acclimation (Mantel \& Farmer 1983), but those data are not presented here. During acclimation, crabs were maintained individually in partitioned, perforated Perspex boxes in $10 \mathrm{l}$ tanks of aerated TMN at $10^{\circ} \mathrm{C}$, under a
$12 \mathrm{~h}$ light:12 h dark cycle. Crabs were not fed during acclimation or exposure periods.

After $7 \mathrm{~d}$ acclimation, crabs were transferred into individual Perspex exposure tanks containing $1 \mathrm{l}$ of exposure medium (TMN) of the required salinity and osmolality, with $50 \mathrm{\mu g} \mathrm{Cd} \mathrm{l}^{-1}$ stable cadmium added as $\mathrm{CdCl}_{2}$, at $10^{\circ} \mathrm{C}$ for $4 \mathrm{~d}$. Each medium was labelled with radioactive $\mathrm{Cd}^{109}$ (Dupont Nen Products) at a concentration of $5 \mu \mathrm{Ci}^{-1}$, with no significant effect on the total dissolved cadmium concentration present.

Blood samples $(0.1 \mathrm{ml})$ were taken from crabs by puncture of the arthrodial membranes of leg joints using a $1 \mathrm{ml}$ syringe with a $0.5 \mathrm{~mm}$ gauge needle (Monoject, Sherwood Medical). Each blood sample was transferred into an acid-washed glass vial. The samples were counted for labelled cadmium on an LKB 1282 Compugamma Universal Gamma Counter. After gamma-counting, each $0.1 \mathrm{ml}$ blood sample was aciddigested with $0.1 \mathrm{ml}$ concentrated nitric acid (Aristar grade, BDH Ltd.) at $100^{\circ} \mathrm{C}$ for $2 \mathrm{~d}$, diluted to $2 \mathrm{ml}$ with double-distilled water, and analysed for total sodium concentration using a Corning 400 flame photometer, calibrated against a series of standards prepared from a $1000 \mu \mathrm{g} \mathrm{ml}^{-1}$ stock (BDH).

The kinetics of the uptake and accumulation of radioactively labelled cadmium in the blood of crabs such as Carcinus maenas are known (Martin \& Rainbow 1998a,b), and the use of parameters of these accumulation kinetics in the blood are established proxy measures of the rate of uptake of dissolved cadmium by the crab (Rainbow et al. 1999, 2000). The labelled Cd concentration in the haemolymph reaches a plateau after 1 or $2 \mathrm{~d}$ as the rate of cadmium uptake into the blood is balanced by its rate of removal. The plateau value $\left(\mathrm{ng} \mathrm{ml}^{-1}\right)$ is directly proportional to the concentration of available $\mathrm{Cd}$ in the exposure solution, and is a relative measure of the crab's uptake rate of dissolved cadmium (Martin \& Rainbow 1998a, Rainbow et al. 1999, 2000). The plateau value was usually calculated as the mean of the data from Days 1 to 4 , unless the specific shape of the kinetics graph for a particular data set indicated that fewer data points should be used as the plateau was reached after Day 1 or had been passed before Day 4 .

Effects of salinity changes. Carcinus maenas: We exposed 6 groups of 5 crabs individually in 11 TMN under the following acclimated (A, B, C) and non-acclimated (D, E, F) salinity conditions: Group A: at a salinity of 33 during $7 \mathrm{~d}$ pre-exposure and $4 \mathrm{~d}$ exposure; Group B: at 20 during $7 \mathrm{~d}$ pre-exposure and $4 \mathrm{~d}$ exposure; Group C: at 15 during $7 \mathrm{~d}$ pre-exposure and $4 \mathrm{~d}$ exposure; Group D: at 33 for $7 \mathrm{~d}$ pre-exposure and at 20 for $4 \mathrm{~d}$ exposure; Group E: at 33 for $7 \mathrm{~d}$ pre-exposure and at 15 for $4 \mathrm{~d}$ exposure; Group F: at 20 for $7 \mathrm{~d}$ pre-exposure and at 33 for $4 \mathrm{~d}$ exposure. 
Eriocheir sinensis: We exposed 7 groups of 8 crabs individually in $11 \mathrm{TMN}$ under the following acclimated (A, B, C, D) and non-acclimated (E, F, G) salinity conditions: Group A: at a salinity of 33 for $7 \mathrm{~d}$ pre-exposure and $4 \mathrm{~d}$ exposure; Group B: at 20 for $7 \mathrm{~d}$ pre-exposure and $4 \mathrm{~d}$ exposure; Group C: at 15 for $7 \mathrm{~d}$ pre-exposure and $4 \mathrm{~d}$ exposure; Group D: at 5 during $7 \mathrm{~d}$ pre-exposure and $4 \mathrm{~d}$ exposure; Group E: at 15 for $7 \mathrm{~d}$ pre-exposure and at 33 for $4 \mathrm{~d}$ exposure; Group F: at 15 for $7 \mathrm{~d}$ pre-exposure and at 20 for $4 \mathrm{~d}$ exposure; Group G: at 15 for $7 \mathrm{~d}$ pre-exposure and at 5 for $4 \mathrm{~d}$ exposure.

Necora puber: We exposed 2 groups of 7 crabs individually in $11 \mathrm{TMN}$ under the following salinity conditions: Group A: at a salinity of 33 for $7 \mathrm{~d}$ pre-exposure and at 33 for $4 \mathrm{~d}$ exposure; Group B: At 33 for $7 \mathrm{~d}$ pre-exposure and at 25 for $4 \mathrm{~d}$ exposure.

Because of the less euryhaline nature of Necora puber, these crabs were maintained in a salinity of 33 and were not acclimated to the lower salinities for the $7 \mathrm{~d}$ pre-exposure to labelled cadmium.

On Day 7 of each experiment, all groups of crabs were exposed to $50 \mathrm{\mu g} \mathrm{l}^{-1}$ cadmium labelled with $5 \mu \mathrm{Ci}$ $\mathrm{l}^{-1} \mathrm{Cd}^{109}$ as a tracer. On most days pre- and during exposure, $0.1 \mathrm{ml}$ haemolymph samples were taken from each crab and measured for labelled cadmium and total sodium concentrations. All 3 species generally showed good regulation of haemolymph $\mathrm{Na}$ concentrations in all salinity experiments (mean $\pm 1 \mathrm{SD}=$ Carcinus maenas, $369 \pm 27 \mathrm{mM} \mathrm{Na}$; Eriocheir sinensis, $440 \pm 52 \mathrm{mM} \mathrm{Na}$; Necora puber, $388 \pm 26 \mathrm{mM} \mathrm{Na}$ ). Full data sets are not presented.

Effects of osmolality changes. The salinity of a solution is a measure of the concentration of inorganic ionic solutes (theoretically defined as the total number of grams of dissolved salt ions present in $1 \mathrm{~kg}$ of seawater, now expressed as a scale without dimensions), while the osmolality of a medium is dependent on the total dissolved particles present (inorganic or organic). A 1 molal solution (containing $1 \mathrm{~mol}$ of solute in $1 \mathrm{~kg}$ of solvent) has an osmolality of $1 \mathrm{Osm} \mathrm{kg}^{-1}$. In seawater, inorganic ions, dominated by sodium and chloride ions, in effect control osmolality and changes in salinity and osmolality occur concurrently as seawater is diluted in estuaries. It is possible, however, for the purpose of these experiments to separate changes in osmolality from those in salinity by the addition of the sugar D-fructose, as used by Nugegoda \& Rainbow (1989b) and Rainbow \& Black (2002).

The osmolality of each of a diluted series of TMN was determined by the freezing point depression method on an Osmette S osmometer (Precision Systems). The osmolalities of TMN with salinities of 33,20, 15, 10 and 5 were 853, 606, 432, 261 and 137 mOsm kg ${ }^{-1}$ respectively. Where required, the osmolality of the solution was raised by addition of the appropriate amount of D-fructose to the TMN (Rainbow \& Black 2002).
Carcinus maenas: We exposed 5 groups of 7 crabs individually in $1 \mathrm{l}$ TMN of the following salinities and osmolalities: Group A: at a salinity of 33 (853 mOsm $\mathrm{kg}^{-1}$ ) during $7 \mathrm{~d}$ pre-exposure and $4 \mathrm{~d}$ exposure; Group $\mathrm{B}$ : at $20\left(606 \mathrm{mOsm} \mathrm{kg}^{-1}\right)$ during $7 \mathrm{~d}$ pre-exposure and $4 \mathrm{~d}$ exposure; Group C: at 15 (432 $\left.\mathrm{mOsm} \mathrm{kg}^{-1}\right)$ during $7 \mathrm{~d}$ pre-exposure and $4 \mathrm{~d}$ exposure; Group D: at 20 $\left(853 \mathrm{mOsm} \mathrm{kg}^{-1}\right.$ ) during $7 \mathrm{~d}$ pre-exposure and $4 \mathrm{~d}$ exposure; Group E: at $15\left(853 \mathrm{mOsm} \mathrm{kg}^{-1}\right)$ during $7 \mathrm{~d}$ pre-exposure and $4 \mathrm{~d}$ exposure.

Eriocheir sinensis: We exposed 5 groups of 5 crabs individually in $11 \mathrm{TMN}$ of the following salinities and osmolalities: Group A: at a salinity of 15 (432 mOsm $\mathrm{kg}^{-1}$ ) during $7 \mathrm{~d}$ pre-exposure and $4 \mathrm{~d}$ exposure; Group B: at 10 (261 $\left.\mathrm{mOsm} \mathrm{kg}^{-1}\right)$ during $7 \mathrm{~d}$ pre-exposure and $4 \mathrm{~d}$ exposure; Group C: at $5\left(137 \mathrm{mOsm} \mathrm{kg}^{-1}\right)$ during $7 \mathrm{~d}$ pre-exposure and $4 \mathrm{~d}$ exposure; Group D: at 10 (432 mOsm $\mathrm{kg}^{-1}$ ) during $7 \mathrm{~d}$ pre-exposure and $4 \mathrm{~d}$ exposure; Group E: at 5 (432 $\left.\mathrm{mOsm} \mathrm{kg}^{-1}\right)$ during $7 \mathrm{~d}$ pre-exposure and $4 \mathrm{~d}$ exposure.

Necora puber: We exposed 3 groups of 7 crabs individually in $1 \mathrm{l}$ TMN of the following salinities and osmolalities: Group A: at a salinity of 33 (853 mOsm $\mathrm{kg}^{-1}$ ) during $7 \mathrm{~d}$ pre-exposure and $4 \mathrm{~d}$ exposure; Group B: at 33 (853 mOsm $\mathrm{kg}^{-1}$ ) during $7 \mathrm{~d}$ preexposure and at $25\left(651 \mathrm{mOsm} \mathrm{kg}^{-1}\right)$ for $4 \mathrm{~d}$ during exposure; Group C: at 33 (853 mOsm kg-1) during $7 \mathrm{~d}$ pre-exposure and at $25\left(853 \mathrm{mOsm} \mathrm{kg}^{-1}\right)$ for $4 \mathrm{~d}$ during exposure.

On Day 7 of each experiment, all groups of crabs were exposed to $50 \mathrm{\mu g} \mathrm{l}^{-1}$ cadmium labelled with $5 \mu \mathrm{Ci}$ $\mathrm{l}^{-1} \mathrm{Cd}^{109}$ as a tracer. On each day during exposure, $0.1 \mathrm{ml}$ haemolymph samples were taken from each crab and measured for labelled cadmium.

Statistical analysis. Statistical analyses were carried out according to Rees (1987) and Sokal \& Rohlf (1969). The null hypothesis $\left(\mathrm{H}_{0}\right)$ tested was that there was no association or difference between variables under test, and rejection of the null hypothesis was at the $5 \%$ probability level $(p<0.05)$. Samples of each data set were normally distributed (checked for homoscedasticity), and the parametric test ANOVA was used to compare means. Tukey's post hoc test was used for all a posteriori testing.

\section{RESULTS}

\section{Effects of salinity changes}

Carcinus maenas. A plateau of labelled cadmium accumulation in the blood was reached in all crabs after 1 to $2 \mathrm{~d}$ of exposure in all treatment groups, and the Days 1 to 4 plateau values were used for ANOVA comparisons between treatment groups. 

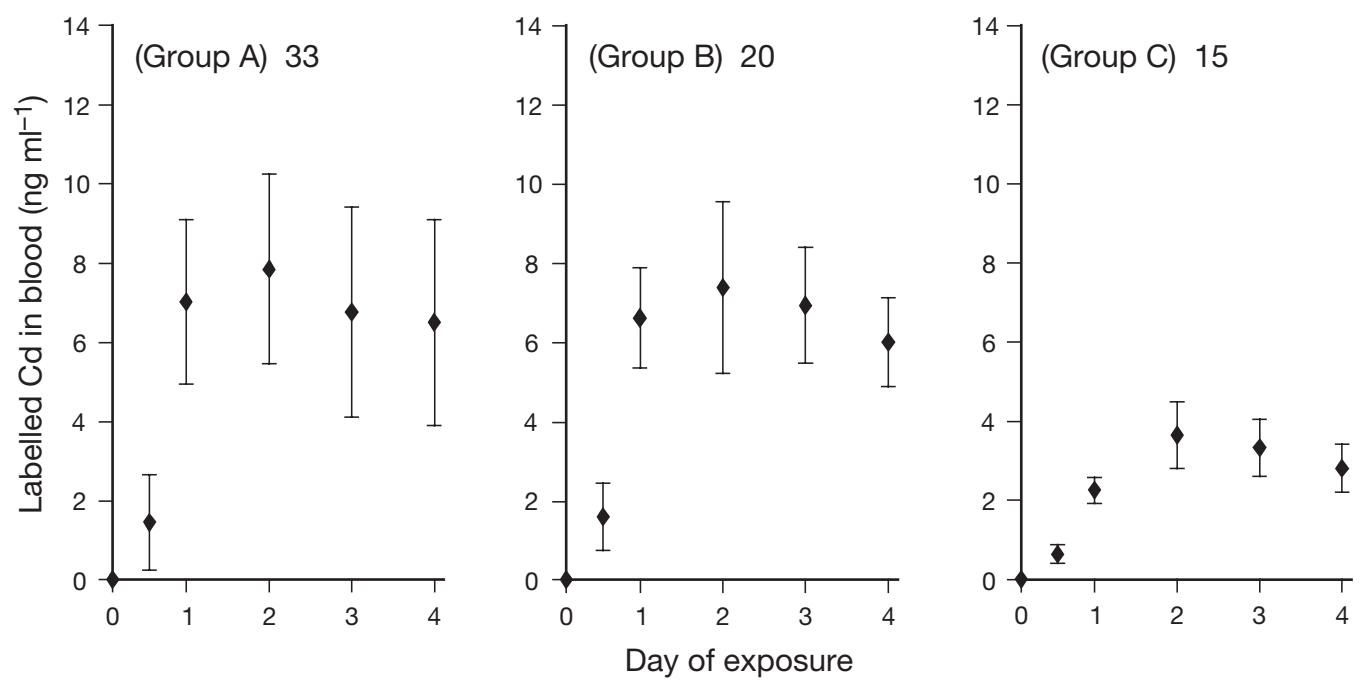

Fig. 1. Carcinus maenas. Uptake (mean $\pm 1 \mathrm{SD}, \mathrm{n}=5$ ) of labelled Cd into blood under acclimated conditions. Crabs exposed for $4 \mathrm{~d}$ to $50 \mu \mathrm{g}$ labelled $\mathrm{Cd} \mathrm{l}^{-1}$ at salinities of 33,20 and 15 after $7 \mathrm{~d}$ pre-exposure at the same salinity

Fig. 1 shows that, under acclimated regimes, the uptake of labelled cadmium into the blood of Carcinus maenas decreased significantly with a decrease in exposure salinity from 33 to 15, i.e. Group A (33) > B (20) $>\mathrm{C}$ (15) (ANOVA A and $\mathrm{B}, F \mathrm{~S}=7.63, \mathrm{df}=2,38, \mathrm{p}<$ 0.01 ; $\mathrm{A}$ and $\mathrm{C}, F \mathrm{~s}=62.7, \mathrm{df}=2,38, \mathrm{p}<0.01$; $\mathrm{B}$ and $\mathrm{C}$, $F \mathrm{~s}=43.2, \mathrm{df}=2,38, \mathrm{p}<0.01)$.

The effect of transfer of crabs from the salinity of 33 in which they had been maintained for $7 \mathrm{~d}$ into a lower salinity during cadmium exposure (i.e. non-acclimated regimes), on the rates of labelled cadmium uptake into the blood was also studied. Fig. 2 shows the results of these exposures and comparisons of the treatments (pre-exposure-exposure salinity) of Group A (33-33) with non-acclimated crabs of Groups D (33-20) and E
(33-15). The rates of cadmium uptake into the blood were not significantly different (ANOVA: Groups A and $\mathrm{D}, F \mathrm{~S}=0.37, \mathrm{df}=2,38, \mathrm{p}=0.55$; Groups $\mathrm{A}$ and $\mathrm{E}$, $F \mathrm{~S}=0.09, \mathrm{df}=2,38, \mathrm{p}=0.77$ ) between crabs kept at 33 salinity and those transferred without acclimation to either of the lower salinities (Groups D 20 and E 15). Fig. 3 shows the results of the reverse experiment. The rate of labelled cadmium entering the blood was not significantly different between crabs acclimated at a salinity of 20 (Group B) and those transferred without acclimation to the higher exposure salinity of 33 (Group F) (ANOVA: Groups B and F, Fs $=0.02, \mathrm{df}=$ $2,38, \mathrm{p}=0.90$ ).

Eriocheir sinensis. Fig. 4 shows the uptake of labelled cadmium into the blood of acclimated crabs
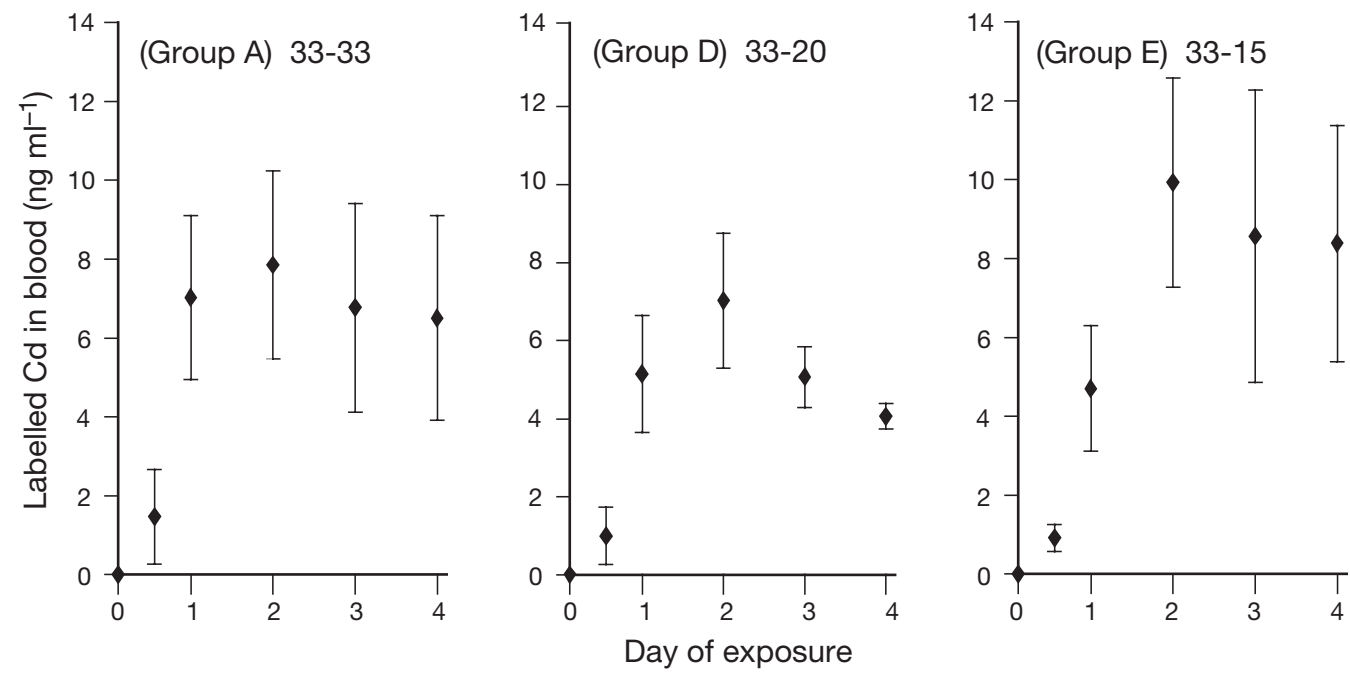

Fig. 2. Carcinus maenas. Uptake (mean $\pm 1 \mathrm{SD}, \mathrm{n}=5$ ) of labelled Cd into blood under non-acclimated conditions. Crabs exposed for $4 \mathrm{~d}$ to $50 \mu \mathrm{g}$ labelled $\mathrm{Cd}^{-1}$ at salinities of 33,20 and 15 after $7 \mathrm{~d}$ pre-exposure at a salinity of 33 


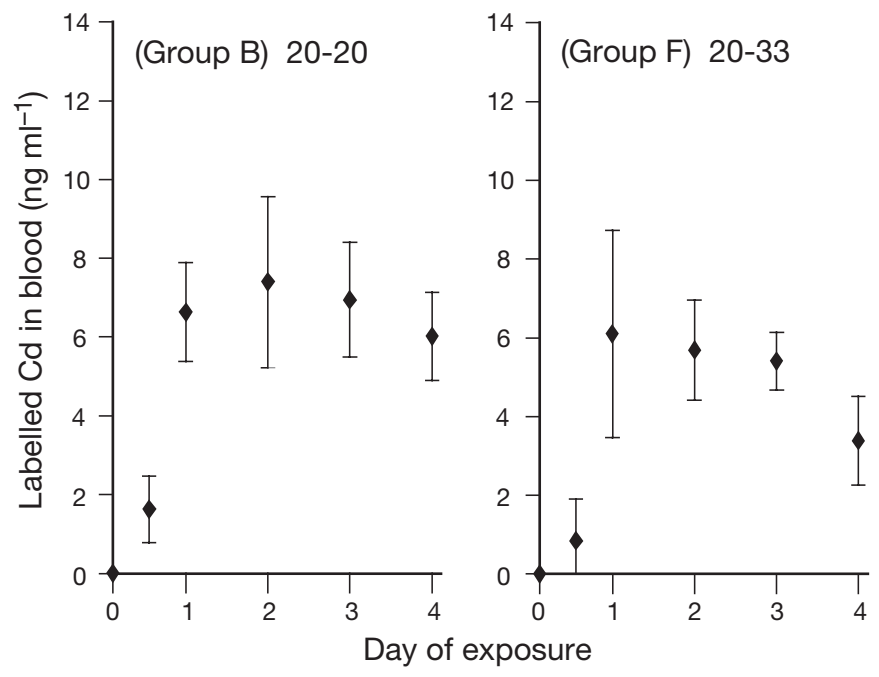

Fig. 3. Carcinus maenas. Uptake (mean $\pm 1 \mathrm{SD}, \mathrm{n}=5$ ) of labelled $\mathrm{Cd}$ into blood under non-acclimated conditions. Crabs exposed for $4 \mathrm{~d}$ to $50 \mu \mathrm{g}$ labelled $\mathrm{Cd} \mathrm{l}^{-1}$ at salinities of 20 and 33 after $7 \mathrm{~d}$ pre-exposure at a salinity of 20

in Groups A (33 salinity), B (20), C (15) and D (5). Comparisons between treatment groups indicated that there was a significant increase in the uptake of labelled cadmium into the haemolymph as salinity decreased from 33 to 5 (Groups $\mathrm{A}<\mathrm{B}<\mathrm{C}<\mathrm{D}$ ) (ANOVA: Groups $A$ and B, Fs = 50.1, df = 2,62, p < 0.01; Groups $\mathrm{A}$ and $\mathrm{C}, F_{\mathrm{S}}=138, \mathrm{df}=2,62, \mathrm{p}<0.01$; Groups $\mathrm{A}$ and $\mathrm{D}$, $F_{\mathrm{S}}=242, \mathrm{df}=2,62, \mathrm{p}<0.01 ;$ Groups $\mathrm{B}$ and $C_{1} F_{\mathrm{S}}=16.5$, $\mathrm{df}=2,62, \mathrm{p}<0.01$; Groups $\mathrm{B}$ and $\mathrm{D}, F \mathrm{~s}=215, \mathrm{df}=2,62$, $\mathrm{p}<0.01$; Groups C and D, Fs $=197, \mathrm{df}=2,62, \mathrm{p}<0.01$ ). At salinity of 5 (Group D), the uptake of labelled cadmium was 10 times higher than the uptake at 33
(Group A), with the labelled cadmium concentration in the blood reaching a maximum concentration of $36.4 \mathrm{ng} \mathrm{ml}^{-1}$.

Crabs in Groups E, F and G were exposed to labelled cadmium at a different salinity than their pre-exposure salinity of 15 , i.e. a non-acclimated regime. Fig. 5 shows the mean uptake of labelled cadmium into the blood of Eriocheir sinensis under Treatments C (15-15), E (15-33), F (15-20) and G (15-5) (preexposure-exposure salinity). The plateau concentrations of labelled cadmium increased significantly with a decrease in exposure salinity from 33 to $5(\mathrm{E}<\mathrm{F}<\mathrm{C}<\mathrm{G})$ (ANOVA: Groups $\mathrm{C}$ and $\mathrm{E}, F_{\mathrm{S}}=263, \mathrm{df}=2,62, \mathrm{p}<0.01$; Groups $C$ and $F_{1} F_{S}=50.6, d f=2,62, p<0.01$; Groups $C$ and $\mathrm{G}, F_{\mathrm{S}}=27.6, \mathrm{df}=2,62, \mathrm{p}<0.01$; Groups $\mathrm{E}$ and $\mathrm{F}_{\text {, }}$ $F \mathrm{~S}=204, \mathrm{df}=2,62, \mathrm{p}<0.01$; Groups $\mathrm{E}$ and $\mathrm{G}, F \mathrm{~s}=36.1$, $\mathrm{df}=2,62, \mathrm{p}<0.01$; Groups $\mathrm{F}$ and $\mathrm{G}, F \mathrm{~s}=31.7, \mathrm{df}=2,62$, $\mathrm{p}<0.01)$. Thus, uptake of labelled cadmium into the haemolymph of acclimated and non-acclimated crabs showed the same pattern, i.e. an increase in uptake rate with decrease in salinity.

Necora puber. Fig. 6 shows the uptake of labelled cadmium into the blood of Necora puber at 33-33 and 33-25 (pre-exposure-exposure salinity). Comparison of uptake values (Days 1 to 4) for Groups A (33-33) and B (33-25) indicated that the uptake of labelled cadmium was significantly reduced on short-term transfer to a lower salinity (ANOVA of treatments [Days 1 to 4 ]: $F \mathrm{~S}=26.1 ; \mathrm{df}=2,54 ; \mathrm{p}<0.01)$.

Comparative uptake rates. Table 1 compares labelled Cd plateau values of the $3 \mathrm{crabs}$ each exposed to $50 \mu \mathrm{g}$ labelled $\mathrm{Cd} \mathrm{l}^{-1}$ at a salinity of 33 at $10^{\circ} \mathrm{C}$. The cadmium uptake rates decreased in the order Necora puber, Carcinus maenas, Eriocheir sinensis under identical physicochemical conditions.
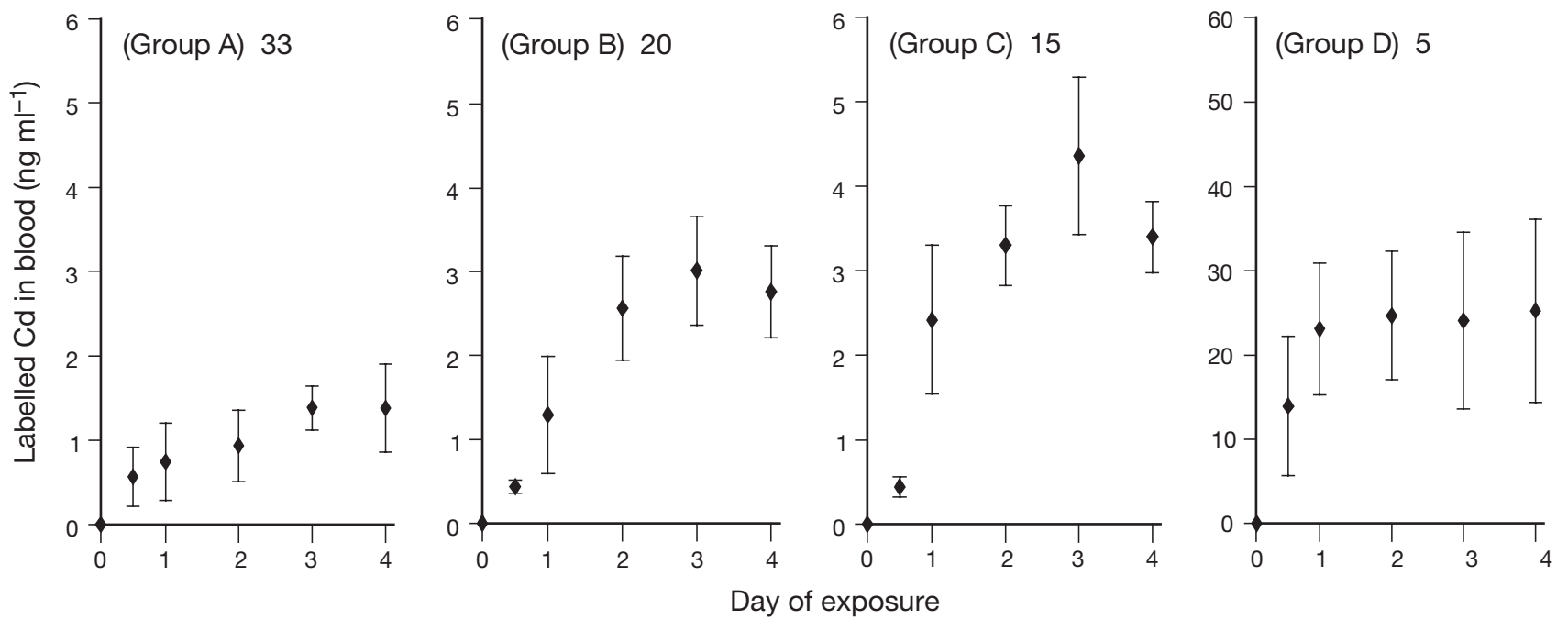

Fig. 4. Eriocheir sinensis. Uptake (mean $\pm 1 \mathrm{SD}, \mathrm{n}=8$ ) of labelled Cd into blood under acclimated conditions. Crabs exposed for $4 \mathrm{~d}$ to $50 \mu \mathrm{g}$ labelled $\mathrm{Cd} \mathrm{l}^{-1}$ at salinities of $33,20,15$ and 5 after $7 \mathrm{~d}$ pre-exposure at the same salinity 

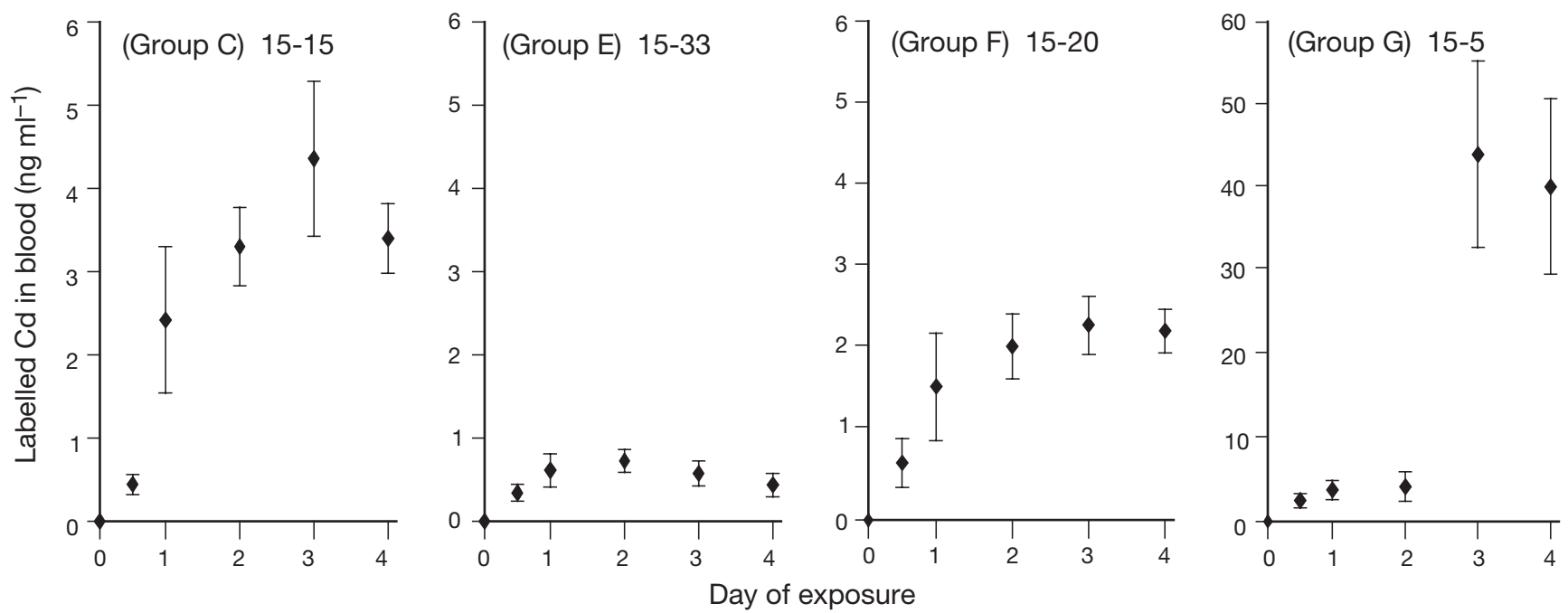

Fig. 5. Eriocheir sinensis. Uptake (mean $\pm 1 \mathrm{SD}, \mathrm{n}=8$ ) of labelled Cd into blood under non-acclimated conditions. Crabs exposed for $4 \mathrm{~d}$ to $50 \mu \mathrm{g}$ labelled $\mathrm{Cd} \mathrm{l}^{-1}$ at salinities of 15, 33, 20 and 5 after $7 \mathrm{~d}$ pre-exposure at a salinity of 15

\section{Effects of osmolality changes}

This series of experiments attempted to separate possible effects of changes in the osmotic pressure of the medium on the physiology of the crabs from the physicochemical effects of changes in salinity on cadmium uptake by the crabs.

Carcinus maenas. Fig. 7 shows that when the osmolality of 20 salinity TMN was raised from 606 mOsm $\mathrm{kg}^{-1}$ (Group B) to 853 mOsm kg-1 (Group D), the uptake of labelled cadmium into the blood did not change significantly (ANOVA: Groups B and D, FS = 1.54 , df $=2,54, p=0.22$ ). However, labelled cadmium

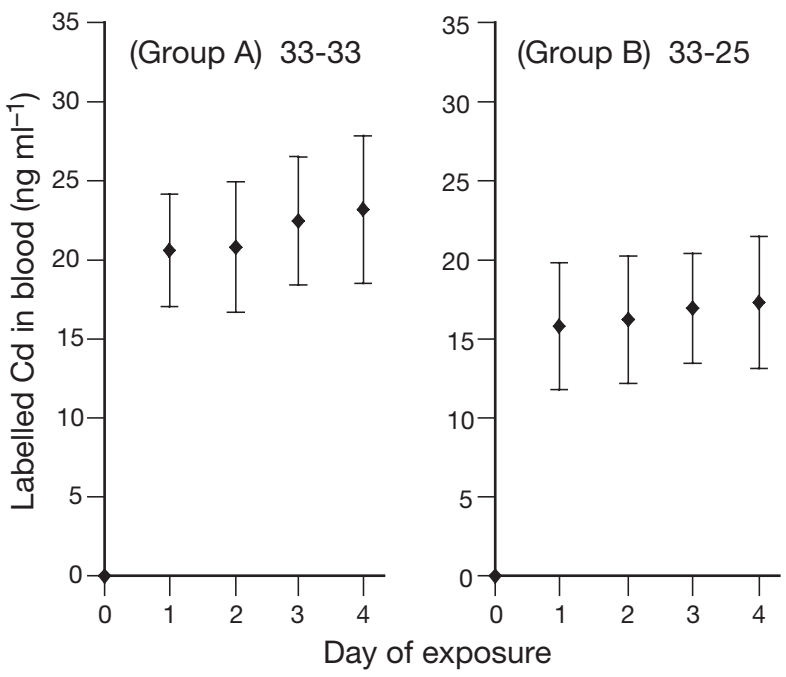

Fig. 6. Necora puber. Uptake (mean $\pm 1 \mathrm{SD}, \mathrm{n}=7$ ) of labelled $\mathrm{Cd}$ into blood. Crabs exposed for $4 \mathrm{~d}$ to $50 \mu \mathrm{g}$ labelled $\mathrm{Cd}^{-1}$ at salinities of 33 and 25 after $7 \mathrm{~d}$ pre-exposure to a salinity of 33 uptake into the blood of crabs in Group B exposed at 20 (853 mOsm $\mathrm{kg}^{-1}$ ) was significantly lower (ANOVA: Groups $\mathrm{A}$ and $\mathrm{B}, F \mathrm{~s}=7.80$, df $=2,54, \mathrm{p}<0.01$ ) than the uptake attained for crabs in Group A exposed at 33 (853 mOsm kg-1).

Fig. 8 shows that the uptake of labelled cadmium into the blood increased significantly as the osmolality of the 15 salinity medium solution was raised to the equivalent osmolality of a 33 salinity medium, i.e. labelled cadmium uptake in Group C crabs (15 salinity at $432 \mathrm{mOsm} \mathrm{kg}^{-1}$ ) was lower than in Group E crabs (15 salinity at $853 \mathrm{mOsm} \mathrm{kg}{ }^{-1}$ ) (ANOVA: Groups C and $\left.\mathrm{E}, F_{\mathrm{S}}=20.4, \mathrm{df}=2,54, \mathrm{p}<0.01\right)$. The uptake of labelled cadmium at 15 salinity/853 mOsm kg-1 (Group E) was significantly lower than the uptake of crabs in Group A

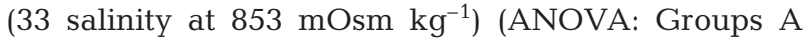
and $\mathrm{E}, F \mathrm{~s}=15.6, \mathrm{df}=2,54, \mathrm{p}<0.01)$.

Eriocheir sinensis. Fig. 9 shows no significant difference (ANOVA: $F \mathrm{~s}=0.08$, df $=2,38, \mathrm{p}=0.77$ ) between the mean uptake plateaux (from Days 1 to 4 ) of labelled cadmium in the blood of crabs in Group B at a salinity of 10 (261 mOsm $\left.\mathrm{kg}^{-1}\right)$ and Group D at a

Table 1. Carcinus maenas, Eriocheir sinensis and Necora puber. Mean ( $\pm 1 \mathrm{SD}$ ) plateau concentrations of labelled Cd in blood (proxy measures of $\mathrm{Cd}$ uptake rates) of crabs exposed to $50 \mu \mathrm{g}$

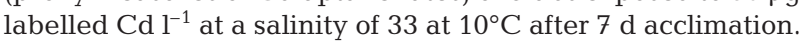

Species shown in order of decreasing Cd uptake rates

\begin{tabular}{|lcc|}
\hline Species & $\mathrm{n}$ & Cd conc. $\left(\mathrm{ng} \mathrm{ml}^{-1}\right)$ \\
\hline Necora puber & 7 & $20.05 \pm 4.05$ \\
Carcinus maenas & 5 & $7.85 \pm 2.39$ \\
Eriocheir sinensis & 8 & $0.93 \pm 0.42$ \\
\hline
\end{tabular}



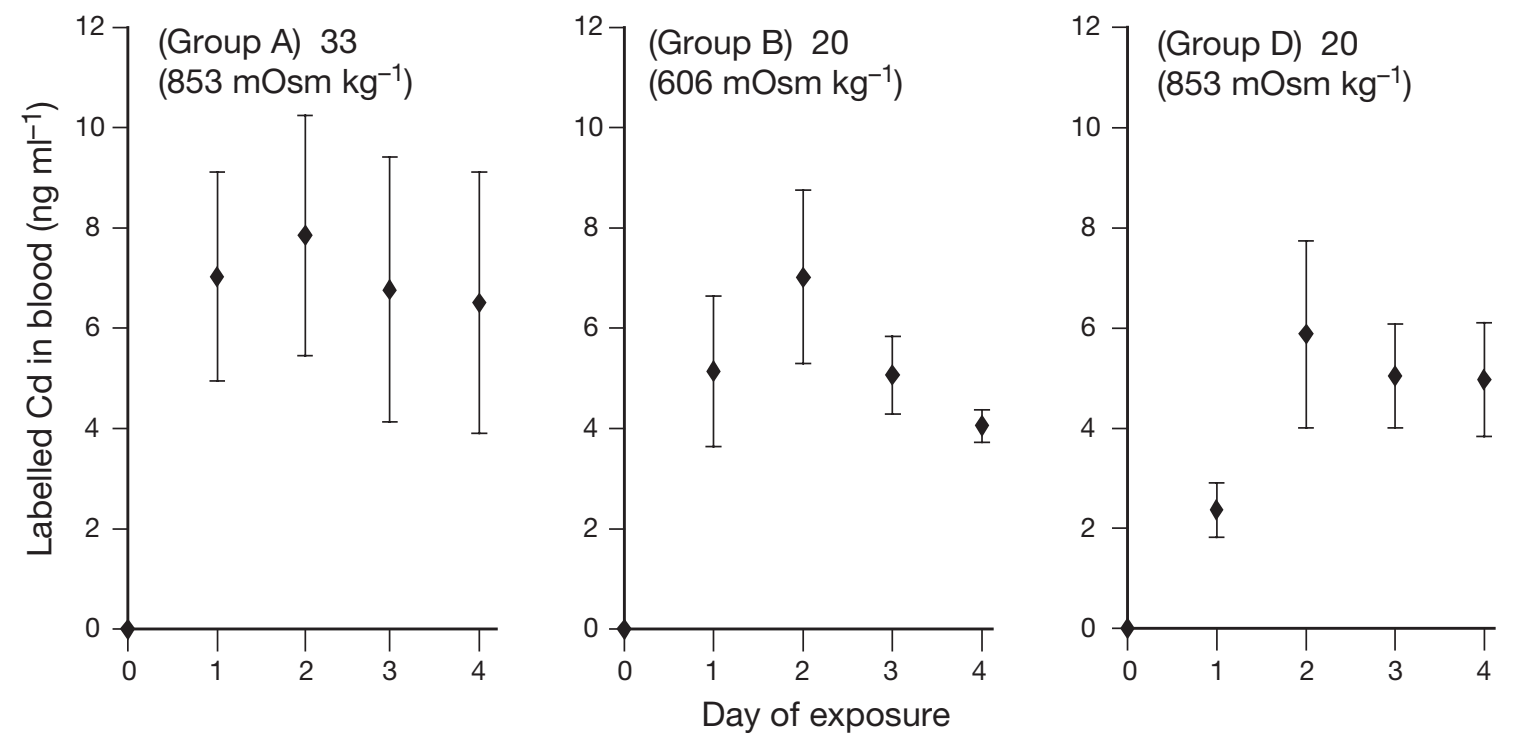

Fig. 7. Carcinus maenas. Effect of changing osmolality on uptake (mean $\pm 1 \mathrm{SD}, \mathrm{n}=7$ ) of labelled Cd into blood of acclimated crabs exposed for $4 \mathrm{~d}$ to $50 \mu \mathrm{g}$ labelled $\mathrm{Cd} \mathrm{l}^{-1}$ at salinities of 33, 20 and 20 adjusted to $853 \mathrm{mOsm} \mathrm{kg}{ }^{-1}$ (equivalent to a salinity of 33) after $7 \mathrm{~d}$ pre-exposure to the same conditions

salinity of 10 (432 mOsm $\left.\mathrm{kg}^{-1}\right)$. The uptake of labelled cadmium was significantly greater at a salinity of 10 (261 and $432 \mathrm{mOsm} \mathrm{kg}^{-1}$ ) than at 15 (432 mOsm kg-1) (Group A) (ANOVA: Groups A and B, Fs $=39.6, \mathrm{df}=$ 2,38, p < 0.01; Groups A and D, Fs = 28.7, df =2,38, p < 0.01; Groups B and D, Fs $=0.08, \mathrm{df}=2,38, \mathrm{p}=0.77$ ).

The mean plateau concentration of labelled cadmium at 5 salinity (Fig. 10) was significantly higher in Group C (137 mOsm $\left.\mathrm{kg}^{-1}\right)$ than in Group E (432 mOsm $\mathrm{kg}^{-1}$ ) (ANOVA: Groups $\mathrm{C}$ and $\mathrm{E}, \mathrm{Fs}=132 \mathrm{df}=2,38$, $\mathrm{p}<0.01$ ). The uptake of labelled cadmium was signifi- cantly greater at 5 salinizy and $137 \mathrm{mOsm} \mathrm{kg}^{-1}$ than at 15 and 432 mOsm kg ${ }^{-1}$ (ANOVA: Groups A and C, $F \mathrm{~s}=132, \mathrm{df}=2,38, \mathrm{p}<0.01)$. When the osmolality of the 5 salinity medium was raised to the equivalent osmolality of a 15 salinity medium, i.e. Group E (5/432 mOsm $\left.\mathrm{kg}^{-1}\right)$, the uptake of labelled cadmium into the blood of the crabs was significantly above that of crabs in Group A $\left(15 / 432\right.$ mOsm $\left.\mathrm{kg}^{-1}\right)$ (ANOVA: Groups $A$ and $E, F S=82.0, d f=2,38, p<0.01$ ).

Necora puber. Fig. 11 shows the effects of raising the osmolality of the 25 salinity exposure medium
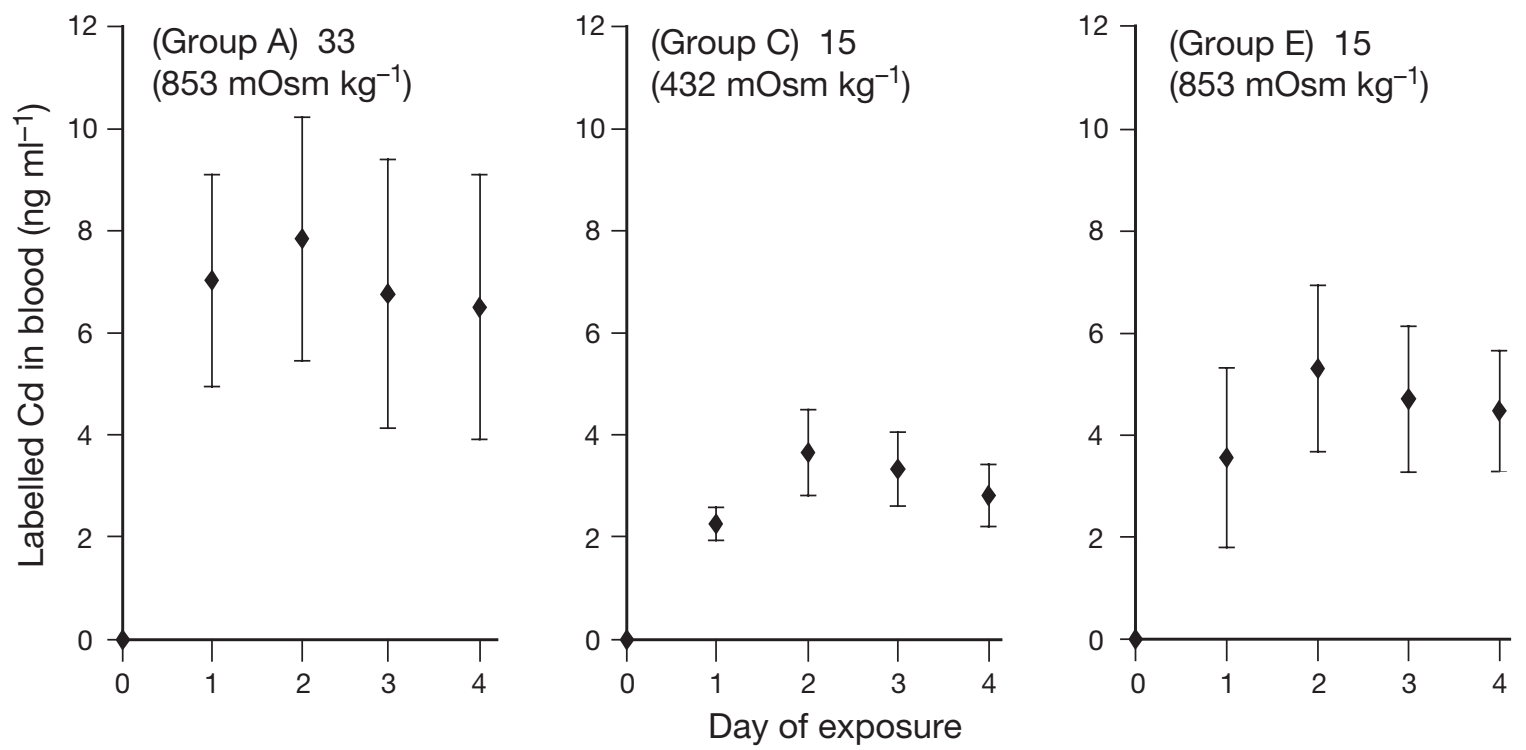

Fig. 8. Carcinus maenas. Effect of changing osmolality on uptake (mean $\pm 1 \mathrm{SD}, \mathrm{n}=7$ ) of labelled Cd into blood of acclimated crabs exposed for $4 \mathrm{~d}$ to $50 \mathrm{\mu g}$ labelled $\mathrm{Cd} \mathrm{l}^{-1}$ at salinities of 33, 15 and 15 adjusted to $853 \mathrm{mOsm} \mathrm{kg}{ }^{-1}$ after $7 \mathrm{~d}$ pre-exposure to the same conditions 

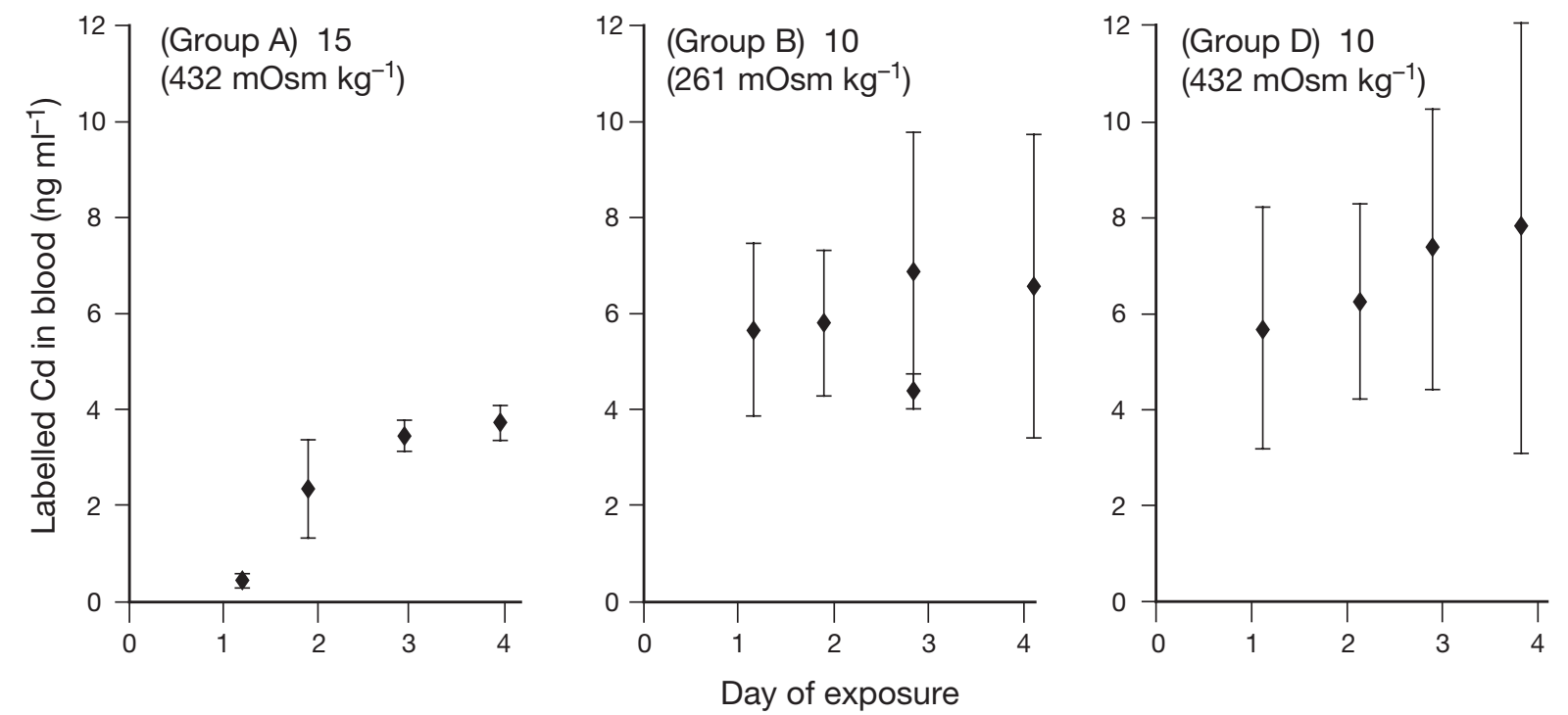

Fig. 9. Eriocheir sinensis. Effect of changing osmolality on uptake (mean $\pm 1 \mathrm{SD}, \mathrm{n}=5$ ) of labelled Cd into blood of acclimated crabs exposed for $4 \mathrm{~d}$ to $50 \mu \mathrm{g}$ labelled $\mathrm{Cd} \mathrm{l}^{-1}$ at salinities of 15, 10 and 10 adjusted to $432 \mathrm{mOsm} \mathrm{kg}{ }^{-1}$ (equivalent to a salinity of 15) after $7 \mathrm{~d}$ pre-exposure to the same conditions

from 651 to $853 \mathrm{mOsm} \mathrm{kg}^{-1}$ on the uptake of labelled cadmium into the blood of Necora puber. Comparison of the mean accumulation (from Days 1 to 4 ) of labelled cadmium into the blood of Groups (B)

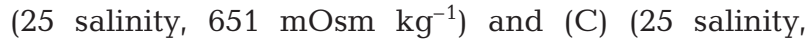
$853 \mathrm{mOsm} \mathrm{kg}{ }^{-1}$ ) indicated that raising the osmolality of the exposure medium had no significant effect on the uptake rates (ANOVA: Groups B and $\mathrm{C}, F_{\mathrm{S}}=$ $0.00, \mathrm{df}=2,54, \mathrm{p}=0.98)$. The uptake of labelled cadmium into the blood was significantly lower at 25 salinity/651 mOsm kg-1 (ANOVA: Groups A and
$\mathrm{B}, F \mathrm{~s}=26.1, \mathrm{df}=2,54, \mathrm{p}<0.01)$ and 25/853 mOsm $\mathrm{kg}^{-1}$ (ANOVA: Groups $\mathrm{A}$ and $\mathrm{C}, \mathrm{Fs}=29.4, \mathrm{df}=2,54$, $\mathrm{p}<0.01$ ) than at $33 / 853 \mathrm{mOsm} \mathrm{kg}^{-1}$.

\section{DISCUSSION}

The effects of changes in salinity on the cadmium uptake rates in crabs acclimated to the different salinities were as predicted from the interpretations of Rainbow \& Black (2002) to explain the data on zinc
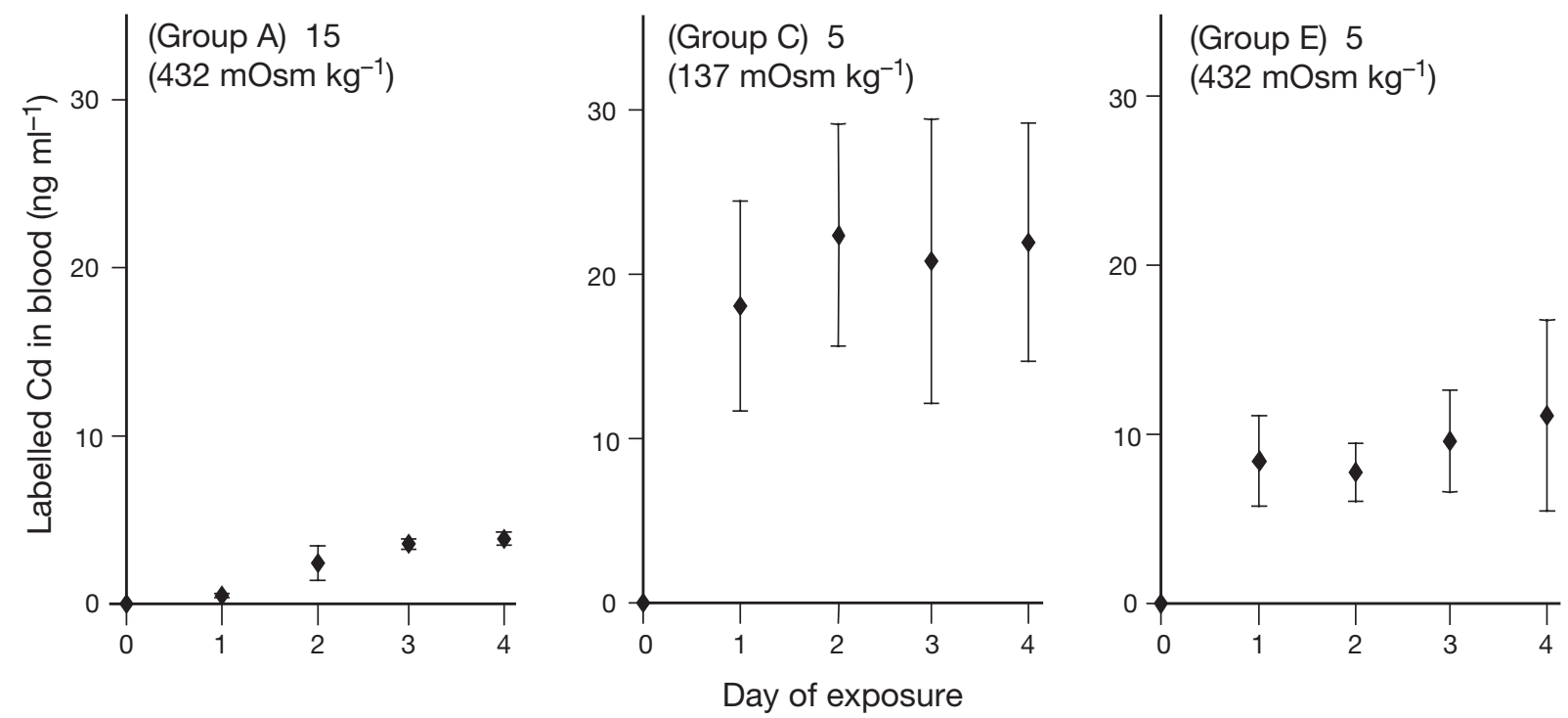

Fig. 10. Eriocheir sinensis. Effect of changing osmolality on uptake (mean $\pm 1 \mathrm{SD}, \mathrm{n}=5$ ) of labelled Cd into blood of acclimated crabs exposed for $4 \mathrm{~d}$ to $50 \mu \mathrm{g}$ labelled $\mathrm{Cd} \mathrm{l}^{-1}$ at salinities of 15,5 and 5 adjusted to $432 \mathrm{mOsm} \mathrm{kg}{ }^{-1}$ after $7 \mathrm{~d}$ pre-exposure to the same conditions 

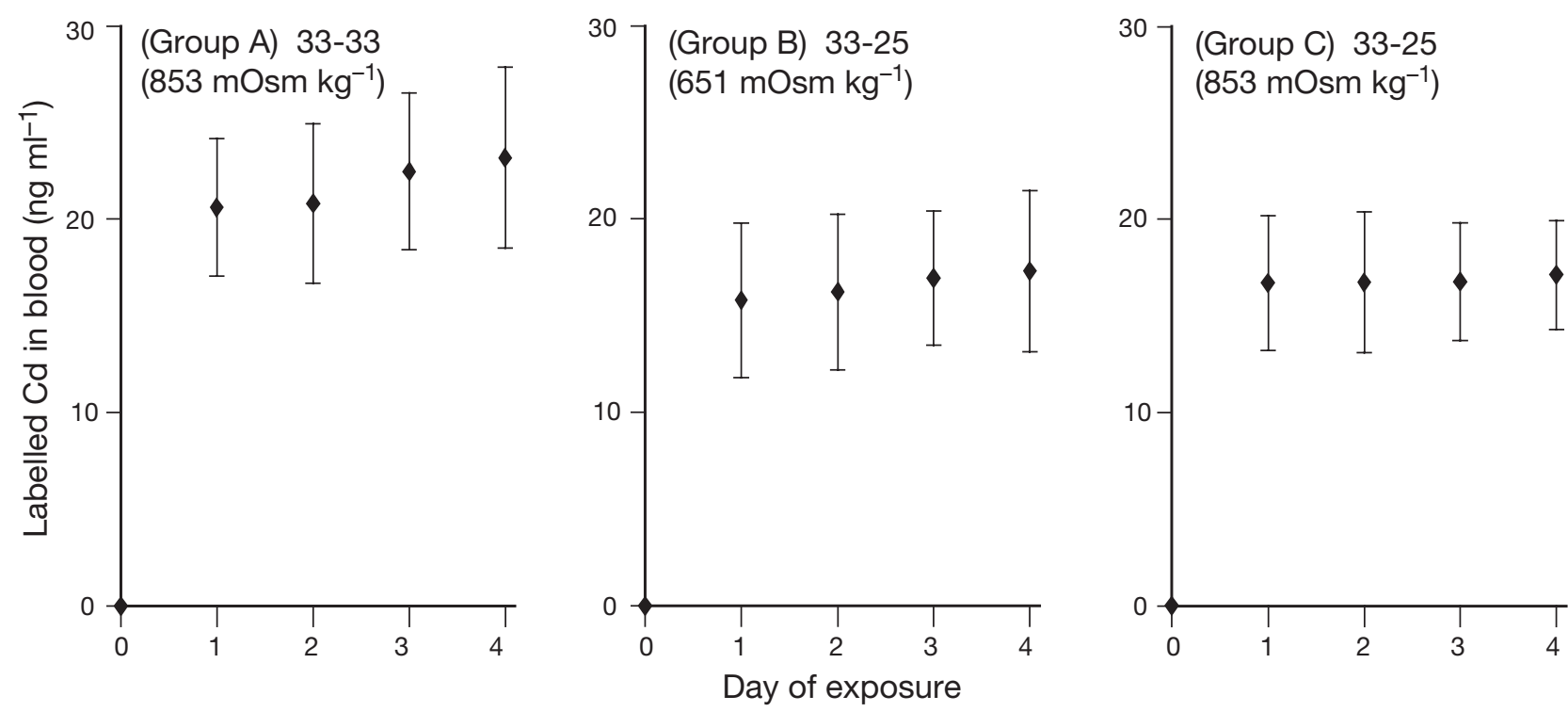

Fig. 11. Necora puber. Effect of changing osmolality on uptake (mean $\pm 1 \mathrm{SD}, \mathrm{n}=7$ ) of labelled Cd into blood of crabs exposed for $4 \mathrm{~d}$ to $50 \mu \mathrm{g}$ labelled $\mathrm{Cd} \mathrm{l}^{-1}$ at salinities of 33,25 and 25 adjusted to $853 \mathrm{mOsm} \mathrm{kg}^{-1}$ after $7 \mathrm{~d}$ pre-exposure to a salinity of 33

uptake rates. The rate of cadmium uptake from solution by acclimated Carcinus maenas decreased as the salinity was reduced from 33 to 15 (Fig. 1). The Cd uptake rate of acclimated Eriocheir sinensis rose with decreased salinity over the salinity range 33 to 5 (Fig. 4). As in the case of Zn uptake (Rainbow \& Black 2002), therefore, the rate of $\mathrm{Cd}$ uptake in $E$. sinensis follows the trend expected from increased free $\mathrm{Cd}$ ion availability with salinity reduction, while $C$. maenas makes a physiological change counteracting and exceeding the physicochemical enhancement effect. A possible contributory physiological response is a change in AWP, which reduces with decreased salinity in the case of $C$. maenas but is relatively unchanged for E. sinensis (Rainbow \& Black 2001, 2002). The much greater increase in Cd uptake rate by $E$. sinensis at the lower end of the salinity range (Fig. 4) is expected from the non-linear increase of the availability of the free $\mathrm{Cd}$ ion with reduced salinity at the lowest salinities (Rainbow et al. 1993).

Changes in AWP in decreased salinity may result from ultrastructural changes in the epithelial cells of the salt-transporting gills, such as regression of the apical infolding system, leading to a decrease in the apical surface area of the cells and the disappearance of the large subcuticular extracellular space (Péqueux 1995). Such morphological changes have the potential to disrupt the number and nature of any trace metal transporting systems present in the apical membranes of the cells, perhaps in relation to the decreased apical surface area of the cells.

In the experiments using non-acclimated crabs, results could be expected to show the onset of physio- logical change in the case of Carcinus maenas and no evidence of physiological change in the case of Eriocheir sinensis.

The rates of Cd uptake in Carcinus maenas transferred without acclimation from a salinity of 33 to salinities of 20 and 15 for Cd uptake showed no significant change (increase or decrease) from the rates of $\mathrm{Cd}$ uptake of crabs maintained at 33 (Fig. 2). It can be argued that the incipient physiological change (not as complete as in acclimated crabs) had in each case been sufficient to match, but not exceed (cf. acclimated crabs), the physicochemical enhancement effect. The physiological reaction to the lower salinity of 15 (see Rainbow \& Black 2001) was stronger than that to the salinity of 20 , and able to balance the stronger physicochemical effect at 15 than at 20. In the case of the reverse experiment (acclimation at salinity of 20 , experiment at 33), there was no significant change in Cd uptake rate (Fig. 3). Perhaps the decreased availability of the free Cd ion was matched by an increase in AWP at the higher salinity, but a more extensive data set is required before any firm conclusions can be drawn. However, in short, the results for nonacclimated C. maenas support the hypothesis proposed, i.e. the crabs are able to make a physiological response counteracting any physicochemical promotion of Cd uptake with reduced salinity.

Non-acclimated Eriocheir sinensis were expected to show the same pattern as acclimated crabs, i.e. increased Cd uptake with exposure to reduced salinities, and indeed this was the case (Fig. 5).

As predicted, Necora puber followed the Carcinus maenas pattern, the rate of dissolved $\mathrm{Cd}$ uptake 
decreasing with salinity reduction from 33 to 25 . The $N$. puber experiments were carried out without acclimation, since prolonged ( $7 \mathrm{~d}$ ) immersion in low salinity is probably never encountered by these crabs in their natural habitat, (low on the shore or sublittorally in fully marine conditions). Nevertheless, $N$. puber can change reduce its AWP during short-term (1 d) exposure to a salinity of 25 (Rainbow \& Black 2001), presumably as an adaptation to short-term tidal emersion in the littoral habitat. Thus, the decrease in Cd uptake rate with reduced salinity in the case of $N$. puber is attributed here to a physiological response overcoming physicochemical enhancement of free $\mathrm{Cd}$ ion availability, as was the conclusion for Zn uptake in N. puber (Rainbow \& Black 2002), and for both Zn uptake (Rainbow \& Black 2002) and Cd uptake (see above) in $C$. maenas.

The comparative rates of $\mathrm{Cd}$ uptake in the $3 \mathrm{crab}$ species under identical physicochemical conditions (Table 1) follow a series compatible with the above interpretation and with published results on their apparent water permeabilities and zinc uptake rates (Table 2). The high Cd and Zn uptake rates of Necora puber correlate with its relatively high AWP (reflected in a low half-time for efflux of water: Table 2), the low $\mathrm{Cd}$ and $\mathrm{Zn}$ uptake rates of Eriocheir sinensis correlating with the low AWP of this crab, while Carcinus maenas is in an intermediate position (Tables 1 \& 2).

What light is thrown on the above interpretation by the experiments varying osmolality independent of salinity, in each case using acclimated crabs? The use of D-fructose to change osmolality but not salinity allows a degree of separation of any physiological response to changing osmotic pressure from the effects of physicochemical changes in $\mathrm{Cd}$ complexation caused by changes to chloride availability associated with salinity change. The assumption made in this logic is that a crab makes a physiological response to a change in osmolality, not in salinity.

In the case of Carcinus maenas, the osmolality experiments would be difficult to interpret if this as-

Table 2. Carcinus maenas, Eriocheir sinensis and Necora puber. Mean $( \pm 1 \mathrm{SD})$ uptake rates of $\mathrm{Zn}$ into blood (proxy measures of $\mathrm{Zn}$ uptake rates) of crabs exposed to $50 \mu \mathrm{g}$ labelled $\mathrm{Zn} \mathrm{l}^{-1}$, and mean $( \pm 1 \mathrm{SD})$ half-times of tritiated water efflux of these crabs at a salinity of 33 at $10^{\circ} \mathrm{C}$ after $7 \mathrm{~d}$ acclimation (after Rainbow \& Black 2001, 2002). Species shown in order of decreasing $\mathrm{Zn}$ uptake rates

\begin{tabular}{|lcc|}
\hline Species & $\begin{array}{c}\text { Zn uptake rate } \\
\left(\mathrm{ng} \mathrm{ml}^{-1} \mathrm{~d}^{-1)}\right.\end{array}$ & $\begin{array}{c}\text { Efflux half-time } \\
(\mathrm{min})\end{array}$ \\
\hline Necora puber & $66.1 \pm 10.3$ & $5.7 \pm 1.4$ \\
Carcinus maenas & $21.3 \pm 5.50$ & $41.4 \pm 5.9$ \\
Eriocheir sinensis & $5.19 \pm 1.66$ & $167 \pm 23.9$ \\
\hline
\end{tabular}

sumption were to hold. Crabs held at a salinity of 15 and equivalent osmolality of $432 \mathrm{mOsm} \mathrm{kg}^{-1}$ had a lower $\mathrm{Cd}$ uptake rate than crabs held at the same salinity but at an osmolality (853 $\mathrm{mOsm} \mathrm{kg}^{-1}$ ) equivalent to a salinity of 33 (Fig. 8), as would be expected from the arguments presented here. Thus, it could be argued that the same availability of free $\mathrm{Cd}$ ions (controlled by chloride concentrations of a medium at a salinity of 15) caused a greater $\mathrm{Cd}$ uptake rate in the crabs at the higher osmolality with, arguably, the higher AWP. So far, so good. The other results at a salinity of 15 (Fig. 8) or 20 (Fig. 7), however, cannot be interpreted using the same logic. Crabs held at a salinity of 15 and osmolality 853 mOsm kg-1 had a lower $\mathrm{Cd}$ uptake rate than crabs at the same osmolality but at the higher salinity of 33 (Fig. 8). This is unexpected. Similarly, the osmolality experiments at a salinity of 20 (Fig. 7) do not fit the expected pattern. Clearly, assumptions made about the factors to which the crabs are responding physiologically are more complex than can be modelled simply by altering osmotic pressures and salinities independently. For example, the crabs might be responding to changes in sodium and chloride concentrations and fluxes, rather than the effects of osmotic pressures on water balance (Mantel \& Farmer 1983, Péqueux 1995). The use of fructose to change osmolality, rather than mannitol or one of the polyethylene glycols, may also have contributed to the lack of clarity here, given the potential passage of fructose across cell membranes.

The osmolality experiments involving Eriocheir sinensis at a salinity of 10 (Fig. 9) were consistent with the lack of any physiological response on the part of this crab under the experimental conditions. Most of the experiments at a salinity of 5 (Fig. 10) were similarly consistent with the lack of physiological response by this crab and, subsequently, control of Cd uptake by physicochemical control of $\mathrm{Cd}$ bioavailability. In 1 experiment, however, the $\mathrm{Cd}$ uptake rate was unexpectedly higher in crabs at a salinity of 5 and osmo-

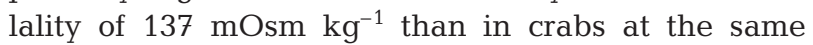
salinity but the higher osmolality of $432 \mathrm{mOsm} \mathrm{kg} \mathrm{kg}^{-1}$ (Fig. 10). This is unexpected since there was no physiological response made by E. sinensis, and is the reverse of the situation in Carcinus maenas. Thus, yet again, the results of the osmolality experiments cannot be explained in terms of a simple response or lack of response to osmolality change independent of salinity change.

Subsequent to these experiments, Roast et al. (2002) investigated cadmium uptake by Ericheir sinensis at salinities either side of the isosmotic point (equivalent to a salinity of 32.7 ), keeping the free $\mathrm{Cd}$ ion concentration constant. There was a great deal of variation between crabs, but the Cd uptake rate of the crabs did 
increase with increased salinity between 22.7 and 42.7 in the absence of physicochemical enhancement of free Cd ion availability (Roast et al. 2002). Thus, in these experiments, the crabs which had been acclimated at 33 did appear to show a physiological response at these high salinities. This physiological response could arguably include a progressive increase in AWP in the high salinity range, but Zn uptake (also under unchanged free $\mathrm{Zn}$ ion availability) did not change, suggesting a more specific physiological response affecting Cd (Roast et al. 2002). Whether this physiological response involves uptake of cadmium via calcium channels remains to be investigated.

The final osmolality experiment involved Necora puber (Fig. 11). As for Carcinus maenas, the results were variable and cannot be interpreted using the simple assumption that the crabs were responding physiologically to osmotic pressure independent of salinity changes. $N$. puber at a salinity of 33 and an osmolality of $853 \mathrm{mOsm} \mathrm{kg}{ }^{-1}$ had a higher Cd uptake rate than crabs at a salinity of 25 and an osmolality of $651 \mathrm{mOsm} \mathrm{kg}^{-1}$ (Fig. 11), suggesting that the physiological response to either salinity or osmolality in the latter crabs outweighed physicochemical enhancement of free $\mathrm{Cd}$ ion availability. Similarly, a physiological response to salinity (not osmolality) would explain the higher $\mathrm{Cd}$ uptake rate of crabs at a salinity of 33 and $853 \mathrm{mOsm} \mathrm{kg} \mathrm{ks}^{-1}$ osmolality than that of crabs at a salinity of 25 and the same osmolality (Fig. 11). The lack of difference between uptake rates of crabs at a salinity of 25 and osmolality 651 mOsm $\mathrm{kg}^{-1}$ and those at the same salinity and the higher

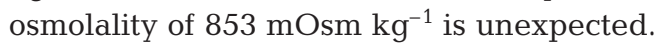

In conclusion therefore, and as predicted, the $\mathrm{Cd}$ uptake rates of Carcinus maenas and Necora puber both decrease with reduced salinity as the crabs respond physiologically to reduced salinity, a response that might well include changes to apparent water permeability. Again as predicted, Cd uptake rates of Eriocheir sinensis increase with decreases in salinity (particularly at the bottom end of the salinity range) as physicochemical enhancement of the availability of the free $\mathrm{Cd}$ ion controls the uptake rate, either in the absence of any counteractive physiological response or in excess of any counteractive physiological response present. The osmolality experiments showed that any physiological responses made are not simply responses to changes in osmotic pressure of the medium, but probably involve some response to salinity change reflected in changes to the concentrations of major ions. The interpretations of Rainbow \& Black (2002) on the uptake of dissolved zinc by these 3 species of crabs are supported by the results obtained here on the uptake of dissolved cadmium.
Acknowledgements. This research was supported by a studentship from the BBSRC (Biotechnology and Biological Sciences Research Council). We would like to thank Brian Smith for his considerable help with experiments.

\section{LITERATURE CITED}

Bruland KW (1983) Trace elements in seawater. In: Riley JP, Chester R (eds) Chemical oceanography, Vol 8. Academic Press, London, p 157-220

Campbell PGC (1995) Interaction between trace metals and aquatic organisms: a critique of the free-ion activity model. In: Tessier A, Turner DR (eds) Metal speciation and aquatic systems. Wiley, New York, p 45-102

Henry RP, Cameron JN (1982) Acid base balance in Callinectes sapidus during acclimation from high to low salinity. J Exp Biol 101:255-264

Mantel LH, Farmer LL (1983) Osmotic and ionic regulation. In: Bliss DE, Mantel LH (eds) The biology of Crustacea, Vol 5. Internal anatomy and physiological regulation. Academic Press, New York, p 53-161

Mantoura RFC, Dickson A, Riley JP (1978) The complexation of metals with humic materials in natural waters. Estuar Coast Mar Sci 6:387-408

Martin DJ, Rainbow PS (1998a) The kinetics of zinc and cadmium in the haemolymph of the shore crab Carcinus maenas (L.). Aquat Toxicol 40:203-231

Martin DJ, Rainbow PS (1998b) Haemocyanin and the binding of cadmium and zinc in the haemolymph of the shore crab Carcinus maenas (L.). Sci Tot Environ 214:133-152

Nugegoda D, Rainbow PS (1988) Effect of a chelating agent (EDTA) on zinc uptake and regulation by Palaemon elegans (Crustacea: Decapoda). J Mar Biol Assoc UK 68: $25-40$

Nugegoda D, Rainbow PS (1989a) Effects of salinity changes on zinc uptake and regulation by the decapod crustaceans Palaemon elegans and Palaemonetes varians. Mar Ecol Prog Ser 51:57-75

Nugegoda D, Rainbow PS (1989b) Salinity, osmolality, and zinc uptake in Palaemon elegans (Crustacea: Decapoda). Mar Ecol Prog Ser 55:149-157

O'Brien P, Rainbow PS, Nugegoda D (1990) The effect of the chelating agent EDTA on the rate of uptake of zinc by Palaemon elegans (Crustacea: Decapoda). Mar Environ Res 30:155-159

Péqueux A (1995) Osmotic regulation in crustaceans. J Crustac Biol 15:1-60

Rainbow PS (1997) Ecophysiology of trace metal uptake in crustaceans. Estuar Coast Shelf Sci 44:169-175

Rainbow PS, Black WH (2001) Effects of changes in salinity on the apparent water permeability of three crab species: Carcinus maenas, Eriocheir sinensis and Necora puber. J Exp Mar Biol Ecol 264:1-13

Rainbow PS, Black WH (2002) Effects of changes in salinity and osmolality on the rate of uptake of zinc by three crabs of different ecologies. Mar Ecol Prog Ser 244:205-217

Rainbow PS, Kwan MKH (1995) Physiological responses and the uptake of cadmium and zinc by the amphipod crustacean Orchestia gammarellus. Mar Ecol Prog Ser 127: 87-102

Rainbow PS, Malik I, O'Brien P (1993) Physicochemical and physiological effects on the uptake of dissolved zinc and cadmium by the amphipod crustacean Orchestia gammarellus. Aquat Toxicol 25:15-30

Rainbow PS, Amiard-Triquet C, Amiard JC, Smith BD, Best SL, Nassiri Y, Langston WJ (1999) Trace metal uptake 
rates in crustaceans (amphipods and crabs) from coastal sites in NW Europe differentially enriched with trace metals. Mar Ecol Prog Ser 183:189-203

Rainbow PS, Amiard-Triquet C, Amiard JC, Smith BD, Langston WJ (2000) Observations on the interaction of zinc and cadmium uptake rates in crustaceans (amphipods and crabs) from coastal sites in UK and France differentially enriched with trace metals. Aquat Toxicol 50: 189-204

Rees DG (1987) Foundations of statistics. Chapman \& Hall, London

Roast SD, Rainbow PS, Smith BD, Nimmo M, Jones MB (2002) Trace metal uptake by the Chinese mitten crab Eriocheir sinensis: the role of osmoregulation. Mar Environ Res 53: 453-464

Simkiss K, Taylor MG (1989) Metal fluxes across the membranes of aquatic organisms. Aquat Sci 1:173-188

Simkiss K, Taylor MG (1995) Transport of metals across membranes. In: Tessier A, Turner DR (eds) Metal specia-

Editorial responsibility: Otto Kinne (Editor-in-Chief), Oldendorf/Luhe, Germany tion and bioavailability in aquatic systems. John Wiley \& Sons, Chichester, p 1-44

Sokal RR, Rohlf FJ (1969) Biometry. The principles and practice of statistics in biological research. WH Freeman, San Francisco

Tessier A, Buffle J, Campbell PGC (1994) Uptake of trace metals by aquatic organisms. In: Buttle J, De Vitre RR (eds) Chemical and biological regulation of aquatic systems. Lewis Publishers, Boca Raton, FL, p 197-230

Williams RJP, Frausto da Silva JR (1996) The natural selection of the chemical elements. Clarendon Press, Oxford

Wright D (1977) The effect of calcium on cadmium uptake by the shore crab Carcinus maenas. J Exp Biol 67:163-173

Wright D (1980) Cadmium and calcium interactions in the freshwater amphipod Gammarus pulex. Freshw Biol 10: 123-133

Zirino A, Yamamoto S (1972) A pH-dependent model for the chemical speciation of copper, zinc, cadmium and lead in seawater. Limnol Oceanogr 17:661-671

Submitted: February 2, 2004; Accepted: July 15, 2004

Proofs received from author(s): January 19, 2005 